\title{
Implementasi Pendidikan Spiritual Dalam Meningkatkan Akhlak Santri Di Pondok Pesantren Subulas Salam Selobekiti Kecamatan Wonosari Kabupaten Malang
}

\author{
Muhammad Dimyati Mabruri, Aris Musnandar \\ Universitas Islam Raden Rahmat (UNIRA) Malang \\ mabruri.dim@gmail.com \\ raries.m1@gmail.com
}

\begin{abstract}
ABSTRAK
Penerapan nilai-nilai akhlak di pondok pesantren menjadi hal yang utama. Penerapan ini dilaksanakan dalam berbagai kegiatan, baik bersifat formal maupun non formal, mengingat pondok pesantren memiliki pendidikan formal. Penelitian ini berjenis penelitian deskriptif kualitatf dan menggunakan kualitatif yang mengedepankan fenomena yang dialami oleh subjek berupa perilaku, persepsi, pandangan, dan motivasi. Data dikumpulkan dengan cara wawancara, observasi, dan studi dokumentasi, sebagai sumber informasi adalah para civitas pondok pesantren Subulas Salam Selobekiti kecamatan Wonosari Kabupaten Malang. Data dianalisis melalui tahap pengumpulan data, reduksi data, penyajian data, dan penarikan simpulan. Selanjutnya pengecekan keabsahan data dengan uji kredibilatas untuk menguji kevalidan data. Hasil penelitian: (1) implementasi nilai-nilai akhlak di pondok pesantren Subulas Salam melalui kegiatan rutin dan wajib, Bentuk implementasi berupa perilaku tawadlu, perilaku disiplin, perilaku hidup sederhana, dan perilaku jujur perkataan dan perbuatan, (2) kegiatan spiritual yang telah diterapkan menjadi harapan semua pihak termasuk santri dalam bertindak dan bersikap yang dibarengi penerapan nilai-nilai salaf untuk mewujudkan nilai tawadlu', nilai kedisplinan, nilai kejujuran, dan nilai kesederhanaan, dan (3) relevansi nilai-nilai spiritual terhadap santri, yaitu terbentuknya perilaku tawadlu, penggunaan waktu yang baik, kegiatan ubudiyah dan amaliyah, dan kejujuran perkataan dan perbuatan.
\end{abstract}

Kata Kunci: Implementasi, Pendidikan Spiritual, Akhlak

\begin{abstract}
The application of moral values in increasing morals in Islamic boarding schools is a need and priority scale. This application is carried out in various activities, both formal and non-formal, considering that Islamic boarding schools known as pondok pesantren (Ponpes) have formal education. This research is a descriptive qualitative research and uses qualitative research that emphasizes the phenomena experienced by the subject in the form of behavior, perceptions, views, and motivation. Data were collected by means of interviews, observation, and documentation study, as a source of information is the civitas Pondok Pesantren Subulas Salam Selobekiti, Wonosari sub-district, Malang Regency. The data were analyzed through the stages of data collection, data reconstruction, data presentation, and drawing conclusions. Furthermore, check validity of the data with the credibility test to test the validity of the data. The results of the research are: (1) that the implementation of moral values in the Subulas Salam
\end{abstract}


Islamic boarding school through routine and compulsory activities, the form of implementation in the form of tawadlu behavior, disciplinary behavior, simple living behavior, and honest behavior in words and actions spiritual values that have been implemented are the hopes of all parties, including students, in acting and behaving accompanied by the application of salaf values to realize the value of tawadlu', the value of discipline, the value of honesty, and the value of simplicity, and (3) that the relevance of spiritual values to students, namely the formation of tawadlu behavior, good use of time, ubudiyah and amaliyah activities, and honesty of words and deeds.

Key words: Implementation, Spiritual Education, Morals

Article History:

Received : 27-11-2020

Revised : 15-04-2021

Accepted : 15-04-2021

Copyright CMabruri, Musnandar

\section{PENDAHULUAN}

Pendidikan spiritual (tarbiyah ruhiyyah) termasuk "nutrisi bergizi tinggi" yang sangat dibutuhkan oleh manusia sehat agar tidak menjauh dari hidayah Allah SWT. Dengan demikian, diharapkan hidupnya tidak mengalami disorientasi, yang dapat menjadi seseorang cenderung materialis, sekuler, hedonis, dan lain sebagainya. Pendidikan spiritual dapat menyehatkan hati dan pikiran, sehingga sikap dan perilakunya menjadi mulia dan rabbani, bukan hewani dan syaithani (berkelakuan seperti hewan dan setan). Istilah pendidikan spiritual di dunia Islam dikenal dengan sebutan ilmu tasawuf. Ilmu tasawuf merupakan ilmu yang memahami dan menghayati pengalamanpengalaman yang pernah dilalui oleh Nabi Muhammad selama kehidupannya.

Pendidikan spiritual bertujuan untuk menciptakan kesempatan mendengarkan suara hati agar mendapatkan kejelasan tentang hal mengapa kita diciptakan dan apa misinya. Ketiga elemen yakni Pikiran, hati dan tubuh berinteraksi secara ideal harmonis satu sama lain. Apabila sudah terpenuhi maka akan membentuk akhlak baik.

Istilah akhlak sudah tidak asing lagi terdengar di tengah kehidupan masyarakat. Mungkin hampir semua orang sudah 
mengetahui arti kata akhlak tersebut, karena perkataan akhlak selalu dikaitkan dengan tingkah laku manusia. Akan tetapi agar lebih meyakinkan pembaca sehingga mudah untuk dipahami maka kata akhlak perlu diartikan secara bahasa maupun istilah. Dengan demikian, pemahaman terhadap akhlak akan lebih jelas substansinya. Secara bahasa kata akhlak berasal dari bahasa Arab yang sudah di-Indonesiakan. Ia merupakan akhlaaq khuluqun. Kata "akhlak" ini mempunyai akar kata yang sama dengan kata khaliq yang bermakna pencipta dan kata makhluq yang artinya ciptaan, yang diciptakan, dari kata khalaqa, menciptakan. Dengan demikian, kata "khulq" dan akhlak yang mengacu pada makna "penciptaan" segala yang ada selain Tuhan yang termasuk di dalamnya kejadian manusia (Aminuddin, 2006: 93) Sedangkan pengertian akhlak menurut istilah adalah kehendak jiwa manusia yang menimbulkan suatu perbuatan dengan mudah karena kebiasaan tanpa memerlukan

pertimbangan

pikiran terlebih dahulu (Hamalik, 2001, p. 57).

Pendidikan spiritual membekali santri tidak hanya kognisi keagamaan, tetapi juga afeksi, apresiasi, dan aktualisasi nilai-nilai moral dan spiritual dalam segala aspek kehidupan. Jika diterjemahkan dalam kehidupan nyata, nilai pendidikan spiritual dapat diaktualisasikan dalam bentuk nilai-nilai perdamaian, seperti: tegur sapa, murah senyum, ramah, semangat memberi pelayanan yang prima, tidak sinis, tidak emosional, mudah mengulurkan tangan. Sementara itu, memberi makan dapat diwujudkan dalam sikap empati, solidaritas sosial, mau meringankan penderitaan orang lain, selalu berbagi, dan berusaha mencari solusi. Selanjutnya, menyambung tali silaturrahim dapat diaktualisasikan dalam bentuk: mudah bergaul, berkomunikasi terbuka dan efektif, tidak bermusuhan, bersahabat, bekerjasama, saling melindungi, dan sebagainya. Hal ini berbeda dengan qiyamul lail 
yang merupakan bentuk spiritualisasi diri dalam perilaku yang senantiasa berzikir kepada Allah, istiqamah dalam beribadah, tekun berdoa, ikhlas beramal, sabar dalam menghadapi cobaan hidup, dan sebagainya.

\section{METODE}

Menurut jenisnya penelitian ini merupakan penelitian kualitatif, dimana peneliti harus mengunakan diri sebagai instrumen kunci sebagai pengumpul data penelitian.Dan berupaya menggali informasi yang sesuai dengan fokus penelitian melalui respoden, peneliti diharapkan fleksibel dan reflektif serta tetap mengambil jarak.Menurut Hadari Nawawi bahwa penelitian kualitatif penelitian yang bersifat atau memiliki karakteristik, bahwa datanya dinyatakan dalam keadaan sewajarnya atau sebagaimana adanya (natural setting), dengan tidak dirubah dalam bentuk simbolsimbol atau bilangan (Nawawi, 2005, p. 174). Pada hakekatnya penelitian kualitatif ini digunakan karena tiga pertimbangan, yaitu: menyesuaikan metode kualiatif lebih mudah apabila berhadapan dengan kenyataan ganda; (2) metode ini 200 menyajikan secara langsuang hubungan antara peneliti dan informan; dan (3)metode ini lebih peka dan lebih dapat menyesuaikan diri dengan banyak penajaman, pengaruh bersama dari terhadap pola-pola yang dihadapi (Moleong, 2001, p. 121).

Pendekatan yang dipakai dalam penelitian ini adalah pendekatan kualitatif, yang bermaksud untuk memahami fenomena tentang apa yang dialami oleh subyek penelitian, misalnya perilaku, persepsi, pandangan, motivasi, tindakan sehari hari, secara holistik dan dengan metode deskripsi dalam bentuk kata-kata dan bahasa (naratif) pada suatu konteks khusus yang alamiah dan dengan memanfaatkan berbagai metode alamiah. Pendekatan ini digunakan agar data yang diperoleh adalah data deskriptif yang berupa kata-kata tertulis dan lisan dari irforman serta dokumen atau perilaku yang diamati.

\section{HASIL DAN PEMBAHASAN}

Secara umum, implementasi bertujuan untuk (1) melaksanakan rencana yang telah disusun dengan cermat, baik oleh individu maupun kelompok., (2) menguji serta mendokumentasikan suatu prosedur 
dalam penerapan rencana atau kebijakan, (3) mewujudkan tujuantujuan yang hendak dicapai di dalam perencanaan atau kebijakan yang telah dirancang, (4) mengetahui kemampuan masyarakat dalam menerapkan suatu kebijakan atau rencana sesuai dengan yang diharapkan, (5) mengetahui tingkat keberhasilan suatu kebijakan atau rencana yang telah dirancang demi perbaikan atau peningkatan mutu.

Demikian pula implementasi nilai-nilai Spiritual di Pondok Pesantren Subulas Salam Kecamatan Wonosari ini, terutama implementasi terhadap nilai-nilai spiritual bertujuan untuk membina spiritual santri secara menyeluruh.

Adapun implementasi terhadap nilai-nilai spiritual yang diterapkan di Pondok Pesantren Subulas Salam Kecamatan Wonosari dalam rangka meningkatkan kecerdasan spiritual.

\section{Perilaku Tawadlu}

Perilaku tawadlu' dalam kegiatan ini, tampak pada waktu pengasuh hadir memasuki ruang kelas. Pada saat itu seluruh santri terdiam seketika dan posisi kepala menunduk sambil menghadap ke kitab kuning yang akan dipelajari. Bahkan ketika

menjawab salam pun tidak berani menatap wajah pengasuh. Ketika proses belajar berlangsung, apabila terdapat santri bertanya kepada pengasuh, mereka merendahkan suaranya dengan bahasa kromo dengan memakai dengan suara lirih, dan lembut. Perilaku tawadlu seperti menundukan kepala, juga terlihat ketika santri berpapasan dengan Kyai atau pengasuh di lingkungan pondok pesantren. Jadi, perilaku tawadlu di Pondok Pesantren Subulas Salam, meliputi sikap sopan santun dalam bertindak dan bersikap, dan merendahkan suara ketika berbicara dengan Kyai atau pengasuh.

Kedua perilaku di atas, juga diterapkan di sekolah formal, walaupun guru yang mengajar bukan berasal dari pondok pensantren. Seluruh siswa akan bersikap dan bertindak santun serta akan merendahkan suaranya ketika berbicara dengan guru, baik di dalam kelas maupun di luar kelas. Perilaku tawadlu di Pondok Pesantren Subulas Salam Kecamatan Wonosari ini telah dicanangkan 
dalam setiap kegiatan.Hal ini terpangpang di dinding pondok agar secara tidak langsung seluruh santri mudah membaca dan memahami segala sesuatu yang berkenaan dengan spiritual yang diterapkan di pondok pesantren.

Untuk membuktikan nilai pendidikan spiritual berupa kedisiplinan dalam meningkatkan kecerdasan spiritual sehari-hari. Sejalan dengan Pendidikan spiritual adalah penguatan spiritual bagi anak dan penanaman iman dalam diri mereka sebagai bentuk pemenuhan kebutuhan naluriyah bergama mereka, menata sifat mereka dengan tata krama dan meningkatkan kecenderungan (tekad, bakat) mereka, dan mengarahkan mereka pada nilanilai spiritual, prinsip, dan suri tauladan yang mereka dapat dari keimanan yang benar pada Allah SWT, malaikat-malaikatnya, kitab-kitabnya, para rasulnya, hari akhir, dan takdir baik dan buruknya. Hasil observasi peneliti pada kegiatan mengaji kitab kuning Riyadhus Sholihin, bahwa perilaku tawadhu' sangat tampak.
Bahwa implementasi nilai pendidikan spiritual yang diaplikasikan di lingkungan Pondok Pesantren Subulas Salam mempunyai dampak yang begitu besar dalam membentuk spiritual dan kebiasaan santri untuk menjadi lebih baik. Bahwa dampak signifikan terhadap pembentukan spiritual santri. Sehingga spiritual pangasuh sedikit demi sedikit akan menular kepada santri dalam kehidupan sehari-hari. Terutama spiritual kepada guru, menghormari orang lain dan lain sebagainya, tetapi terdapat cara lain dalam menerapkan pendidikan spiritual santri Pondok Pesantren Subulas Salamdalam kehidupan seharihari yaitu dengan membentuk pengurus yang menangangi masalah etika dan adab santri. Dan indikator perilaku tawadlu' ketika mengaji kitab kuning, yaitu perilaku tawadlu' dalam kehidupan sehari di pondok pesantren atau di luar pondok.

Bahwa nilai tawadhu dalam hal berpakaian yang tidak berlebihan ini menunjukkan kesetaraan dari masing-masing santri, hal ini tercermin ketika terdapat 
kegiatan mengaji. Begitu juga tentang nilai tawadhu tentang sopan santun dalam bertindak dan bersikap, tercermin ketika santri berjumpa dengan pangasuh atau kyai di jalan lingkungan pondok. Para sastri terdiam dan menunduk sampai sang pengasuh atau kyai melewati. Pengasuh mengklaim bahwa Pondok Pesantren Subulas Salam termasuk tipologi pesantren kholaf (modern),walupun berperilaku kholaf, tetapi masih mempertahan nilai-nilai tawadhu'. sebagaimana hasil wawancara dengan pengasuh utama sekaligus termasuk salah satu putra pendiri Pondok Pesantren Subulas Salam. Hal ini juga disampaikan oleh pengasuh lain bahwa nilai tawadlu'dimulai dengan hal kecil yang misalnya dapat meniru orang-orang yang lebih senior dari kita, sehingga kita dapat mengambil hal penting yang dapat kita tiru, dalam hal ini spiritualnya. Sikap meniru sikap dan tingkah laku senior (santri yang sudah lama mondok) baik hal-hal yang sifatnya sepele seperti menata sandal pengasuh, yang seluma menghadap ke depan diubah mengahdap ke belakang agar ketika pengasuh pulang langsung memakai. Di samping itu, hormat, dan tunduk pada setiap Kyai, Ustadz dan Ustadzah saat berpapasan maupun bercengkarama.

2. Perilaku Disiplin dalam Mengikuti Kegiatan

Perilaku disiplin diterapkan di Pondok Pesantren Subulas Salam Kecamatan Wonosari ini melalui proses binaan di dalam kamar pondok, proses pendidikan, dan juga pergaulan sehari-hari, seprti mandi, makan dan sholat berjamaah di masjid. Berarti perilaku disiplin diterapkan dalam pendidikan formal (sekolah umum) dan pendidikan non formal (madrasah diniyah). Di samping itu, perilaku disiplin ini diterapkan agar setiap santri memiliki nilai-nilai kedisiplinan, seperti hadir tepat waktu ke sekolah atau mengaji kitab kuning, kegiatan upacara di madrasah Ibtida'iyah, madrasah Tsanawiyah, atau di madrasah Aliyah, apalagi kegiatan sholat berjamaah di masjid. Khusunya, pendidikan non formal adalah 
pendidikan yang bertujuan untuk mengganti, menambah, dan melengkapi pendidikan formal, teruma nilai-nilai spiritual.

Adapun bentuk implementasi nilai-nilai spiritual seperti kedisiplinan di pendidikan non formal seperti pondok pesantren, khususnya di Pondok Pesantren Subulas Salam Kecamatan Wonosari merujuk pada hasil observasi dalam kegiatan mujahadah bahwa kegiatan Mujahadah ini rutin dilaksanakan setiap hari Selasa setelah sholat Dhuhur berjama'ah.Kegiatan mujahadah juga disebut usbusyah. Setelah sholat Dhuhur berjma'ah, imam dari mujahadah dari pengasuh atau ustad ponpes mengawali dengan memberi tausiah kepada santri untuk membawa santri ke suasana khusu' dan hening selama 15 menit.Kemudian dengan suasana yang khusu', santun dan disiplin tempat sesuai shof sholat yang lurus.Dimulailah dengan aurat sholawat wahidiyah yang berfaedah untuk menghantarkan santri, ma'rifat kepada Allah dan Rasulnya melalui jalan pemantapan batin atau ruhani santri.Pembacaan sholawat Wahidiyah sebagai mujahada para santri.Ini berlangsung kurang lebih 75 menit.Setelah mujahadah usai para santri bersalaman dengan imam mujahadah, dan temanteman santri lainya dg santun dan menjaga kedisiplinan.

Kegiatan mengkaji kitab-kitab akhlak setelah ba'da sholat maghrib menjadi hal yang dianggap penting dan dianggap besar manfa'atnya sehingga santri merasa kehilangan jika tidak hadir.Kedisplinan, dan kasih sayang terhadap sesama, saling menghargai, berusaha untuk selalu, tidak menyakiti orang lain.Untuk lebih jelasnya, terdapat beberapa kegiatan belajar yaitu: (1) pengajian Pengasuh, (2) mengaji kitab Tasawuf, (3) sholawat Wahidiyah, (4) manaqib, sholat berjama'ah dan wirid, (5) sholat Tahajud dan Witir. Sebagaimana Pandangan Aminuddin yang mengutip pendapat Ibnu Maskawah (w.421H/1030M) yang memaparkan defenisi kata spiritual ialah kondisi jiwa yang senantiasa mempengaruhi untuk 
bertingkah laku tanpa pemikiran dan pertimbangan (Aminuddin, 2006, p. 94).

Selain untuk merangkai sanad kitab yang dipelajari, kegiatan ini juga melestarikan ajian yang diwariskan oleh pendiri pondok pesantren. Di samping itu, untuk menambah kedekatan pengasuh dengan santri,karena jelas, pengaruh karismatik pengasuh akan berdampak terhadap kepribadian santri untuk menjadi kepribadian yang luhur. Hal ini sejalan dengan Pendapat lain dari Dzakiah Daradzat mengartikan spiritual sedikit lebih luas yaitu kelakuan yang timbul dari hasil perpaduan antara nurani, pikiran, dan kebiasaan yang menyatu, membentuk suatu kesatuan tindakan spiritual yang dihayati dalam kenyataan hidup keseharian (Drajat, 1993, p. 10).

Kegiatan kajian kitab kuning di Pondok Pesantren Subulas Salam Kecamatan Wonosari, mengingat jadwal mengaji kitab kuning dilakukan setiap malam, kecuali hari Kamis malam Jum'at.Selanjutnya santri mempersiapkan diri untuk belajar di madrasah formal, kegiatan mulai santri bangun pagi sampai tidur kembali.Pendidikan karakter yang prioritaskan terlebih dahulu adalah membentuk karakter santri agar disiplin, tertib, jujur dan taat pada peraturan serta nilai riligius.

Maka dari itu, jelas bahwa implementasi nilai pendidikan spiritual di Pondok Pesantren Subulas Salam dengan cara memberikan stimulus pada santri supaya terbiasa aktif dan harapannya adalah dapat menjadi karakter dalam dirinya. Santri tidak hanya mendapatkan dalam satu bidang ilmu saja, melainkan juga secara tanpa sadar membawa karakter baik pada kepribadian dirinya, menariknya, pembiasaan aktif dan disiplin tersebut dengan tanpa menyuruh atau memberikan hukuman, melaikan dengan tanpa sadar mereka tersedot untuk aktif dan antusias untuk mengikuti kegiatan tersebut. Karena, mereka penasaran atas pertanyaan dan jawaban baru dari teman sekelasnya. 
Sebagaimana ciri khas pondok pesantren bahwa di dalamnya terdapat santri, Kyai, musholla, penginapan dan ruang untuk kuliah. Sehingga para santri mencari ilmu sekaligus bertempat tinggal di tempat tersebut. Dengan demikian, maka di dalam pondok pesantren tersebut mempunyai kultur yang unik. Terlebih dalam hal nilai pendidikan spiritual yang bersifat sosial.

Setelah peneliti adakan observasi dan wawancara bahwasannya Pondok Pesantren Subulas Salam mempunyai santri kurang lebih 300 santri putra-putri. Dengan jumlah santri yang bisa di bilang begitu banyak tersebut, tentunya tidak mudah untuk menerapkan pendidikan spiritual terhadapt santri, hingga sampai tercipta kultur yang memiliki spiritual mulia. Dan kebiasaan ini yang juga akan di bawa santri kelak ketika pulang ke kampungnya masing-masing.

Mengetahui penerapan nilai pendidikan spiritual yang di lakukan oleh Kyai dan pengurus Pondok Pesantren Subulas Salam, peneliti melakukan wawancara dengan pengasuh dan beberapa pengurus. Secara umum, Pondok Pesantren Subulas Salam mempunyai cara sendiri untuk menanamkan nilainilai pendidikan spiritual terhadap santri yang bersifat prosedural. Dengan prosedur tersebut, secara tidak langsung akan membentuk kultur yang prosedural dan sistemik. Adapun undang-undang atau tata tertib Pondok Pesantren Subulas Salam setelah peneliti adakan observasi dan wawancara dipaparkan yaitu kewajiban umum, kewajiban khusus, larangan santri, dan sanksisantri.

Dari tata tertib atau undangundang Pondok Pesantren Subulas Salam yang tersebut di atas, dapat diamanati bahwa hal itu dilakukan untuk menerapkan nilai-nilai pendidikan spiritual terhadap santri adalah melalui kebiasaan. Artinya, dengan diwajibkannya santri mematuhi tata tertib tersebut jika terus dilakukan akan dapat membentuk nilai Spiritual santri agar menjadi lebih baik, sehingga akan dibawa ke kampungnya masing-masing,karena santri 
yang mondok di Pondok Pesantren Subulas Salam mempunyai karakterdan latar belakang yang berbeda-beda.

Pengurus ini di sebut dengan divisi katertiban, bahwa ketertiban yang merupakan salah satu divisi pengurus Pondok Pesantren Subulas Salamyang mengurusi santri dalam hal tingkah laku dan moral santri termasuk bagian darifaktor pendukung penerapan nilai pendidikan spiritualdi Pondok Pesantren Subulas Salam dalam meningkatkan kecerdasan spiritual santri. Dengan demikian, tugas divisi ketertiban sangat berat, karena mereka memang harus sabar dan ulet dalam menangangi santri terutama santri yang nakal. Sesungguhnya pendidikan spiritual yang benar digambarkan sebagai salah satu alat ukur (standar ukuran) dalam menumbuh kembangkan macammacam kepribadian manusia yang berbeda dengan pertumbuhan/ perkembangan yang lengkap (mencakup segala hal), ialah sumber petunjuk bagi akal (Hamid, n.d.). Perilaku tersebut diciptakan melalui proses binaan di dalam pondok pesantren, proses kedisiplinan yang mewujudkan pengalaman sehari-hari. Disiplin bukanlah sikap yang dangkal yaitu sekedar menaati dan mengikuti aturan saja, melainkan sikap hati yang tulus karena memiliki tujuan yang hendak diraih. Nilai Kedisiplinan direalisasikan dalam kegiatan pengajian, peserata diwajibkan untuk tidak berbicara dengan teman lainnya. Selain itu, setiap siswa yang tidak hadirakan mendapatkan sanksi tertentu sesuai dengan pelanggaran yang dilakukan.

Selain itu, terdapat kegiatan yang menjadi ciri khas pondok pesantren yaitu pengajian pengasuh dengan sistem sorogan, artinya pengasuh membacakan kitab klasik tertentu dengan makna jawanya kemudian santri memaknainya. Dalam kegiatan ini nilai-nilai spiritual yang diterapkan adalah kedisiplinan, yaitu kegiatan santri mengikuti dan mendengarkan penjelasan sang kyai sangat khusuk, artinya santri bersikap disiplin yang diikuti oleh seluruh santri dan 
apabila terdapat santri yang tidak hadir dalam kegiatan tersebut akan menerima sanksi dari pengurus pondok sesuai yang diperintahkan oleh sang kyai. Adapun yang berkaitan dengan kedisiplinan santri, idungkapkan olehsalah satu pengurus dan ketua bidang Ta'limiyah (Pendidikan) Pondok Pesantren Subulas Salam, bahwa kegiatan pengajian pengasuh dengan model kuno mempunyai nilai yang dapat merangsang kesadaran santri akan pentingnya mencari ilmu, disiplin dan aktif dalam mengikuti kegiatan. Di samping itu, karismatik pengasuh mempunyai pengaruh yang sangat besar, memang tenaga pengajar sudah seharunya mempunyai karismatik dengan cara memberi teladan yang baik, komitmen dan penuh percaya diri.

\section{Perilaku Hidup Sederhana}

Sederhana berarti meninggalkan kemewahan dan sikap berlebihan dalam kemubahan dunia adalah sikap terpuji.Baik dalam pakaian, makanan, minuman, kendaraan, tempat tinggal dan lain-
lain.Kesederhanaan yang diajarkan dalam pondok pesantren juga mencakup kesederhanaan dalam perkataan dan perbuatan. Prilaku tidak melampaui batas dalam perkataan dan perbuatan hingga termasuk kategori sia-sia atau diharamkan oleh Allah swt adalah tujuan dari sejumlah larangan-larangan memakai perhisaan bagi santri perempuan, apalagi mengambil barang temuan orang lain.

Ihwal penampilan, sebagaimana yang telah tercantum dalam kode etik santri, yaitu santri harus berpenampilan sederhana dan rapi ketika berada di luar komplekPondok Pesantren Subulas Salam, hal ini juga banyak membuahkan hasil dalam mendidik spiritual para santri. Sebagaimana yang disampaikan nara sumber, sebagai guru Pondok Pesantren Subulas Salam, bahwa implementasi nilai pendidikan spiritual berupa perilaku sederhana yang dilakukan oleh Pondok Pesantren Subulas Salam berawal dari sebuah peraturan yang kemudian akan menjadi sebuah budaya 
yang harapannya dapat melekat dalam diri masing santri.

Berdasarkan pernyataanpernyataan dari pandangan di atas, dapat disimpulkan bahwa penerapan yang dilakukan oleh Pondok Pesantren Subulas Salam dalam mendidik spiritual santri di kehidupan sehari-hari adalah dengan cara mengawal seluruh kode etik Pondok Pesantren Subulas Salam yang berupa tata tertib, khususnya pakaian sederhana. Perilaku hidup sederhana yang dibuat oleh pengasuh utama tersebut dapat menghasilkan perilaku baru sesuai dengan perkembangan zaman yang ditetapkan oleh pengasuh atau pengurus pesantren. Harapannya,agar perilaku hidup sederhana yang telah tersusun tersebut dapat menjadi nilai spiritual yang diterapkan dalam diri santri dan terus dilakukan ketika pulang ke kampungnya masing-masing.

Bahwa Pondok Pesantren Subulas Salam ini sangat menjunjung tinggi nilai pendidikan spiritual.Baik dari sisi religius, berpakaian, makanan, tempat tinggal, terlebih terhadap sikap dan tingkah laku yang baik.Hal sangat mendidik santri sebagai pedoman hidup baik untuk diri sendiri maupun ketika menjalani hidup di masyarakat kelak, kontribusi yang besar terhadap perkembangan bangsa yang cerdas dan bermartabat ini mampu melahirkan generasi yang menjadi harapan semua pihak, yaitu orang tua, dan pengasuh pondok pesantren.

\section{Perilaku Jujur dalam Perbuatan}

Bentuk perilaku yang paling populer di masyarakat adalah jujur dalam perkataan. Seorang yang senantiasa berkata jujur akan mendapatkan kepercayaan dari orang lain dan tentunya dikasihi oleh Allah swt, tetapi jika seorang itu berdusta, maka orang lain tidak akan mempercayainya. Kejujuran dalam perketaan dapat memperluas pergaulan, sebab orang yang berprilaku jujur tentu akan banyak disenangi orang, dan tidak membuat perasaan khawatir serta curiga terhadap temannya, apalagi dalam menjalinihidup bermasyarakat akan damai dan tentram, lebihlebih memperoleh keridhoan dari Alloh swt. 
Perilaku kejujuran, khususnya dalam perkataan di Pondok Pesantren Subulas Salam diterapkan dalam setiap tindakan dan perbuatan yang dilakukan oleh santri ketika mengikuti kegiatan formal atau non formal.Perilaku kejujuran ini berkaitan dengan nilai kejujuran yang telah dipaparkan pada fokus 1 yaitu nilai-nilai spiritual yang diterapkan di Pondok Pesantren Subulas Salam Kecamatan Wonosari pada bagian terkahir.

Berdasarkan paparan tentang implementasi nilai-nilai spiritual berupa perilaku kejujuran tersebut, dapat disimpulkan bahwa perilaku kejujuran yang dilakukan di Pondok Pesantren Subulas Salam Kecamatan Wonosari dimulai dari para pengurus dan pengasuh. Hal ini diterapkan agar santri memiliki panutan dalam perkataan dan perbuatan. Jadi, Sumber spiritual adalah yang menjadi ukuran baik dan buruk atau mulia dan tercela. Sebagaimana keseluruhan ajaran agama Islam, sumber spiritual adalah al-Quran dan sunnah, bukan akal pikiran atau pandangan masyarakat sebagaimana pada pandangan konsep etikadan moral. Dan bukan pula karena baik atau buruk dengan sendirinya sebagaimana pandangan Mutazilah (Aminuddin, 2006, p. 96). Jadi, nilai-nilai spiritual yang berupa nilai tawadhu', nilai kedisplinan, nilai kesederhanaan, dan nilai kejujuran yang diterapkan oleh Pondok Pesantren Subulas Salam ini sejalan dengan pandangan bahwa sifat yang tertanam dalam jiwa yang menimbulkan perbuatanperbuatan dengan gampang dan mudah, tanpa memerlukan pemikiran dan pertimbangan. Jika sifat itu merupakan perbuatan yang baik menurut akal dan syariat, maka disebut spiritual yang baik, dan bila lahir darinya perbuatan yang buruk, maka disebut spiritual yang buruk (Ilyas, 2006, p. 2).

\section{KESIMPULAN}

Berdasarkan hasil pembahasan temuan penelitian yang berjudul Implementasi Pendidikan Spiritual dalam meningkatkan akhlak santri di Pondok Pesantren Subulas Salam Selobekiti Kecamatan 
Wonosari Kabupaten Malang Malang dapat ditarik kesimpulan:

1. Bahwa nilai-nilai pendidikan akhlak yang

diimplementasikan dalam mengingkatkan kecerdasan spiritual santri di Pondok Pesantren Subulas Salam Selobekiti Kecamatan Wonosari ini berbentuk nilai tawadlu', nilai kedisplinan, nilai kejujuran, dan nilai kesderhanaan. Keenpat nilai tersebut dilaksanakan dalam kegiatan mengaji kitab kuning dengan metode sorogan yang dipimpin langsung oleh Kyai Sepuh yang karismatik menjadi harapan santri dalam bertindak dan bersikap positif yang dibarengi dengan penerapan nilai-nilai salaf.

2. Bahwa implementasi nilai-nilai akhlak dilaksanakan di Pondok Pesantren Subulas
Salam Selobekiti Kecamatan Wonosari melalui kegiatan yang sudah terjadwal, seperti kegiatan mujahadah, zuhud, pembacaan sholat, pembacaan manaqib, sholat berjama'ah dan wirid, dan mengaji kitab kuning, serta sholat tahajud diperoleh hasil implementasi pendidikan akhlak ini, berupa perilaku tawadlu, perilaku displin, perilaku hidup sederhana, dan perilaku jujur dalam perbuatan.

Relevansi nilai-nilai akhlak terhadap santri yakni terbentuknya sikap tawadlu terhadap pengasuh, sikap disiplin di setiap kegiatan, sikap sabar dalam keta'atan beribadah, dan sikap jujur dalam perbuatan. Keempat sikap ini diwujudkan dalam kegiatan sholat berjama'ah setiap waktu dan kegiatan religius mengaji kitab kuning oleh 
pengasuh, muhadloroh kubro, dan musyawarah malam mendalami ilmu agama melalui kitab kuning dengan 5 (lima) tingkatan, yaitu kelas Ula, kelas Wustho, kelas Ulya, kelas Ma'had Ali 1 dan 2.

\section{Daftar Pustaka}

Aminuddin. (2006). Membangun Karakter dan Kepribadian Melalui Pendidikan Agama Islam. Jakarta: Graha Ilmu.

Drajat, Z. (1993). Pendidikan Islam dalam Keluarga dan Sekolah. Jakarta: CV. Ruhama.
Hamalik, O. (2001). Kurikulum dan pembelajaran. Jakarta: Bumi Aksara.

Hamid, A. (n.d.). usul al-tarbiyah alislamiyah fi al-sunnah annabawiyah. Tunis: Darul Arabiyah lil Kitab.

Ilyas, Y. (2006). Kuliah Spiritual. Yogyakarta: Pustaka Pelajar Offset.

Moleong, L. J. (2001). Metodologi Penelitian Kualitatif. Bandung: Pt. Rosda Karya.

Nawawi, H. (2005). Penelitian Terapan. Yogyakarta: Gajah Mada University Press. 